\title{
Institutional Leadership and Perceived Performance: Evidence from the Korean Minister Survey*
}

\author{
Kwangho Jung** and Jongwon Choi***
}

\begin{abstract}
Few empirical studies have explored Selznick's ideas on institutional leadership's role in creating, nourishing, and maintaining public institutions. Reconsidering and expanding Selznick's perspective, this study explores how perceived ministerial performance is associated with institutional leadership styles. Using data from the 2007 Korean Minister Survey, this study develops five types of institutional leadership (visionary, persuasive, resilient, coalition network, and maintaining) derived from an exploratory factor analysis and tests their association with ministers' performance. It suggests that visionary leadership and persuasive leadership are the primary determinants of Korean ministers' performance, and their effects are greater for ministers without presidential support. Resilient leadership and coalition network leadership are also significantly associated with ministers' performance, but maintaining leadership has little effect on it. Moderating effects on the relationship between leadership type and performance include presidential support and the presence of a performance crisis. Further research is needed to develop different measures for ministerial performance from different sources in order to avoid the common method bias.
\end{abstract}

Keywords: institutional leadership, ministerial leadership, organizational performance

\section{INTRODUCTION}

Since Philip Selznick's seminal work Leadership in Administration (1957), institutional leadership has long been neglected in public organizations. ${ }^{1}$ The focus of the

\footnotetext{
* This work was supported by a grant from the National Research Foundation of Korea, funded by the Korean government (NRF-2010-330-B00031).

** Kwangho Jung, corresponding author, is an associate professor in the Graduate School of Public Administration, Seoul National University. E-mail: kwjung77@snu.ac.kr.

*** Jongwon Choi is a professor in the Graduate School of Public Administration, Seoul National University.
}

Manuscript received March 3, 2011; out for review March 10, 2011; review completed April 8, 2011; accepted April 20, 2011.

The Korean Journal of Policy Studies, Vol. 26, No. 2 (2011), pp. 45-75.

(C) 2011 by the GSPA, Seoul National University 
mainstream literature on leadership has ranged from supervisory leadership to transformational leadership within organizations. ${ }^{2}$ Traditional leadership has ignored core components of institutional leadership such as rhetoric and coalition-building skills to promote and protect institutional values and missions. ${ }^{3}$ The Selznick's core message is that organizational performance or success depends on institutional leadership to cope with the ambiguity and uncertainty of organizations.

Leadership studies in the public sector have also ignored the important aspects of public organizations compared to private organizations(Getha-Taylor et al., 2011). ${ }^{4}$ Compared to top executives in private organizations, public leaders spend much of their time fending off challenges from rival agencies, coping with criticism from the media and interest groups, and trying to retain presidential and legislative support. Gaining legitimacy and reputation is important for the survival of public organizations (Wilson, 1989, pp. 196-197). All of these jobs require successful institutionalization. However, mainstream literature on leadership and institutionalism has not directly discussed who institutionalizes organizations and how.

The role of leadership in creating, developing, and maintaining institutions has been long neglected in traditional leadership studies. Only a few studies have reconsidered Selznick's ideas on institutional leadership. For instance, Doig and Hargrove (1987) argue that public leaders play a key role in effective institutionalization using rhetoric and coalition-building skills. Two recent studies reconsider Selznick's seminal ideas on institutional leadership: Washington and his colleagues (2005) explore three functions of institutional leaders: (1) managing internal consistency, (2) developing external supporting mechanisms to enhance the legitimacy of the organization, and (3) overcoming external enemies to protect and maintain institutional integrity. Boin and Christensen (2008) emphasize the role of leadership in the development of public institutions. However, specific elements of institutional leadership remain unexplored.

1. The earlier version of institutional leadership came from Chester Barnard, The Function of Executive (1938) and more recent studies of institutional leadership include Thorton and Ocasio (1999), Podolny, Khurana, and Hill-Popper (2005), and Boin (2008).

2. Nohria and Khurana (2010) provides a very nice review on leadership research from various academic disciplines including institutional leadership studies.

3. Selznick (1957) addressed three core elements of institutional leadership: defining and embodying the mission and role of the organization; defending its integrity of purpose and action; and resolving conflicts by balancing internal and external demands.

4. Gether-Taylor and her colleagues (2011) review previous public leadership studies in terms of the character of public leadership, the function of public leadership, and the jurisdiction of public leadership and emphasizes the study of public leadership within public administration, rather than trying to borrowing theories of business management and politics. 
There is little empirical evidence as to how they are related to leaders' performance.

This study examines various attributes of institutional leadership at the ministerial level and how they are associated with performance in South Korea, using data collected from middle- and high-ranking public servants in 13 departments by the 2007 Korean Minister Survey. By focusing on how career civil servants evaluate their ministers' leadership performance, this study explores the following question: What types of institutional leadership exist in government organizations, and which institutional leadership attributes do subordinates consider important to ministerial performance? To explore these questions, this study introduces a framework of institutional leadership in terms of the locus and mechanism of institutionalization and develops five institutional leadership dimensions.

\section{PRESENT RESEARCH ON INSTITUTIONAL LEADERSHIP}

This section explores leadership studies associated with institutional leadership in complex public organizations. Drawing on Selznick's Leadership in Administration, we define institutional leadership as the role of (1) developing and infusing the mission of the organization, (2) nourishing external supporting mechanisms to enhance the legitimacy of the organization, and (3) conserving distinctive institutional values and integrity. Selznick's work has become a classic on the art of institutional leadership. However, his ideas on the role of institutional leadership have been neglected for more than 50 years (Washington, Boal, \& Davis, 2008). Nevertheless, we can draw some characteristics of institutional leadership from various fields: institutional theory of entrepreneurship (DiMaggio, 1988), transformational leadership (Bass, 1985, 1990; Burns, 1978), conservatorship (Terry, 1995), multifaceted perspectives (Denis, Langley, \& Rouleau, 2005), and case-oriented top executive studies. We first reconsider Selznick's ideas on institutional leadership and explore components of institutional leadership from the above five fields.

\section{Reconsidering Selznick's Seminal Work}

Many studies have simply cited Selznick's Leadership in Administration as providing the famous definition of institutions as organizations "infused with value," rather than as identifying key characteristics of institutional leadership to promote and protect institutional values and missions. However, Selznick's primary objective in this book is to understand how leadership transforms an organization into an institution. ${ }^{5}$ He emphasizes that effective leaders are able to define, defend, and sustain the organi- 
zation's institutional values and its distinctive mission beyond efficiency. He describes two types of institutional leadership: creative and responsible. The art of the creative leader is the art of institution building, enabling the organization to embody new and enduring values (Selznick, 1957, pp. 152-153). Creative leadership emphasizes keeping the institution in constant flux and renewing its. These jobs require responsible leadership that transcends specialism. Leadership is not responsible when it fails to set the basic mission of the organization.

\section{Institutional Theory of Entrepreneurship}

Recent studies of institutional theory have addressed the innovative role of entrepreneurs (DiMaggio, 1988; Fligstein, 1997). Institutional entrepreneurs play a creative role in institutional change. Institutional entrepreneurship to embed value and legitimize new institutional elements can be regarded as a special case of institutional leadership. It represents the activities of actors who leverage resources to create new institutions or to transform existing ones (DiMaggio, 1988). Key roles of institutional entrepreneurs are to frame issues, mobilize constituencies, and infuse new values into social structures (Rao et al., 2000, p. 240). However, Terry (1995) argues that such entrepreneurial behaviors deinstitutionalize the traditional norms and distinctive core values in public organizations.

\section{Transformational Leadership}

Transformational leadership has become a classic leadership model in organizational studies (Bass, 1985; Burns, 1978). Core functions of transformational leadership are very similar to Selznick's ideas on institutional leadership. For instance, transformational leaders motivate their followers by articulating a vision of the organization's mission (inspirational motivation). They also encourage their followers to work toward the mission (idealized influence). Transformational leaders encourage their followers to challenge and redefine problems and practices (intellectual stimulation). These three characteristics of transformational leadership, like Selznick's institutional

5. Selznick describes an organization as a rational instrument to achieve goals, and an institution as a responsive and adaptive organism (1957, p. 5). He refers to institutions as having become "infused with value beyond the technical requirements at hand" (1957, p. 17). An organization becomes an institution only when its leader infuses it with values and a sense of direction. The responsibility of the executive is to transform the organization into an institution. In doing so, the "executive becomes a statesman as he makes the transition from administrative management to institutional leadership" (1957, p. 4). 
leadership, transform an organization into an institution by promoting organizational values and missions beyond organizational efficiency. In addition, transformational leadership fits well with institutionalism. It directly addresses the process of valuation and the instilment of values within an organization. However, it is an irony that almost all studies of transformational leadership have neglected Selznick's original ideas and do not fully consider the ideas of institutional theory. Transformational leadership alone is not enough, because it neglects a capacity for creating and maintaining the systems and institutions (Selznick, 1957; Nye, 2008). It also ignores the traditions embedded in public institutions (Terry, 1995).

\section{Conservatorship: Terry's Administrative Leadership}

Terry (1995) suggests a model of "administrative conservatorship" in which bureaucratic leaders should have a guardianship role to preserve institutional integrity. It is necessary to defend and strengthen existing institutions and values. He addressed three major functions of public administrators (leaders). First, administrators preserve institutional integrity, which prevents institutional decay. Second, they protect institutional autonomy, allowing public bureaucracies to preserve their distinctive values, competence, and role. Third, they respond to their stakeholders, such as elected officials, clients, and interest groups. Terry's ideas come from Selznick's functional approach, and his administrative conservators are institutional leaders. However, the conservatorship model does not provide a clear vision of how to reform public organizations and services. Whereas entrepreneurial leadership relies on technical rationality, administrative conservatorship is based on substantive rationality and concerned with morality and trust.

\section{Multifaceted Perspectives: Network, Value, and Social Construction}

Denis, Langley, and Rouleau (2005) present the idea that public leadership is embedded in the whole political and administrative environment, characterized by diffuse power, divergent values, and complex systems of rules. They introduce three emergent views of leadership: a network perspective, a value perspective, and a practice perspective. These frameworks address how top executives develop strategic plans through networks, how they harmonize conflicts with competing values, and how they become skilled practitioners within the complex web of public organizations. The network perspective identifies four sub-processes in building a network: (1) defining a problem and creating a network to solve it, (2) fixing the interests of key actors together, (3) assigning key roles and building an alliance, and (4) expanding the 
initial network. The value perspective focuses on how leaders establish sustainable decisions and strategies in an administrative context of conflicting objectives and competing demands of stakeholders. The model emphasizes the bridge role of co-leaders embedded in the competing values of different worlds. The practice perspective defines leadership as a social process in daily routines and micro-conversations, where leadership is socially constructed through practices and discourses. Constructive leadership requires social skills (for example, motivation and communication) and social intelligence (for example, learning from experiment and active listening) to identify how leadership is constituted and realized.

\section{Recent Case-Oriented Research on Institutional Leadership}

Case studies of leadership have provided key elements of institutional leadership. They come from two fields: case studies of public leaders and case studies of institutional entrepreneurs. All of these studies illustrate how organizational performance depends on various types of institutional leadership.

Since Leadership in Administration was published in 1957, some case studies have explored innovative institutional leadership behaviors. For instance, Lewis (1984) has provided a valuable study of the institutional role of entrepreneurial actors in public bureaucracies. ${ }^{6} \mathrm{He}$ describes, for example, how J. Edgar Hoover expanded the FBI's scope and autonomy and professionalized the police investigative function. Doig and Hargrove (1987) identify key components of institutional leadership from 14 top executives in US federal agencies. In this study, public entrepreneurs identify new missions and programs, create and nourish external constituents to support new goals, create internal constituencies through changes in organizational structures, and enhance the organization's technical expertise to implement new goals and programs. Doig and Hargrove (1987) summarize two key components of institutional leadership: rhetoric and coalition-building skills. ${ }^{7}$ Riccucci (1995) describes three institutional leadership

6. Lewis discusses Hyman Rickover, the admiral who oversaw the development of the US nuclear submarine; J. Edgar Hoover, the FBI director who made national security into a permanent big (public) business; and Robert Moses, the city planner who shaped New York State through the development of parks, roads, and bridges.

7. David Lilienthal emerges as an organizational myth-making executive who led the Tennessee Valley Authority from 1933 to 1946, took new ideas and planted the public image of his agency's "grass roots" deep enough for it to survive and prosper well into the 1970s. Nancy Hanks, when chair of the National Endowment for the Arts from 1969 to 1977, forged an alliance in support of public culture. The allies included cultural institutions, newly formed arts service organizations, influential members of Congress, and White House staffers. 
skills in US federal executives: (1) political skills, to develop a strong working relationship with a key political appointee and an effective approach to legislative and interest-group politics; (2) network skills, to develop internal and external support mechanisms; and (3) adaptive skills, to cope with situational factors such as financial problems and legislative opposition.

Recent case studies in European countries have also explored various ministerial roles and leadership styles. For instance, Chabal (2003) and Rhodes (2005), relying on field research and ethnographic analysis, explore their impact on public policy. Ministerial studies in the United Kingdom (Andeweg, 2000; King, 1994; Marsh, Richards, \& Smith, 2000) characterized ministers as having a dual role: setting policy within their departments while increasingly exercising political and public relations functions in dealing with external stakeholders, such as the president, media, and legislators.

Relying on the Korean Minister Survey, Jung, Moon, and Hahm (2008) find that strategic-transformational leadership is the most important determinant of a minister's perceived performance, and external-transformational leadership (in both the politicalcooperative and president-cooperative forms) is also positively associated with a minister's perceived performance.

Institutional research has also addressed the role of the individual as a leading actor in a complex system of public organizations and as an innovative creator of new institutions (e.g., DiMaggio, 1988; Christensen, Karnoe, Pedersen, \& Dobbin, 1997). Denis, Lamothe, and Langley (2001) draw on five case studies in health care organizations to conceptualize a unified collective leadership that allows for a distinctive role and for all members to work together harmoniously. Mintzberg and McHugh (1985) describe the successful institutionalization of the National Film Board of Canada, reconciling two competing demands: preserving the autonomy of filmmakers (the inspirational world) and setting up an efficient organization (the industrial world). Jarzabkowski (2003) addresses the strategic role of the top management team in three UK universities in changing existing routines and generating more funds through sharing interpretation.

\section{ANALYTICAL FRAMEWORK OF INSTITUTIONAL LEADERSHIP AND PERFORMANCE}

\section{Typology of Institutional Leadership}

As discussed in the previous section, Selznick's ideas on institutional leadership are fragmentarily distributed across various disciplines. Institutional theory posits that an institutional actor's role is to promote and protect institutional integrity, but still 
presents an unclear picture of how institutional actors construct institutionalization with internal constituents and external stakeholders. The transformational leadership model provides a clear framework for understanding how leaders motivate followers through normative and persuasive institutionalization, but does not explain how leaders maintain and reaffirm institutional values and missions. Terry's (1995) conservatorship approach emphasizes the administrator's role in maintaining traditional values and ethics in public organizations. The network perspective, the value perspective, and the social practice perspective describe a variety of interactive leadership styles as a social process. All these approaches have discussed leadership roles. However, they do not comprehensively capture the nature of institutional leadership in terms of locus and mechanism of institutionalization. A systematic analysis of institutionalization is necessary to fully identify the characteristics of institutional leadership. Figure 1 proposes a framework for discussing the various styles of institutional leadership.

Figure 1. Institutional Leadership Typology

\begin{tabular}{|c|c|c|c|}
\hline & & \multicolumn{2}{|c|}{ Locus of Institutionalization } \\
\hline & & \multicolumn{2}{|c|}{ Selznick's Creative Leadership and Responsible Leadership } \\
\hline & & Internal Constituents & External Stakeholders \\
\hline \multirow{5}{*}{ 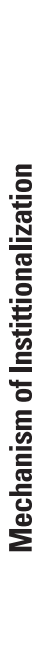 } & $\begin{array}{l}\text { Acculturation } \\
\text { (normative, } \\
\text { minetic } \\
\text { socialization) }\end{array}$ & $\begin{array}{l}\text { Transformational leadership } \\
\text { - Charismatic leadership } \\
\text { - Visionary leadership }\end{array}$ & $\begin{array}{l}\text { Social constructive leadership } \\
\text { - Civil leadership } \\
\text { - Political socialization leadership }\end{array}$ \\
\hline & $\begin{array}{l}\text { Persuasion } \\
\text { (soft power) }\end{array}$ & $\begin{array}{l}\text { Transformational leadership } \\
\text { - Internal persuasive leadership } \\
\text { - Democratic leadership } \\
\text { (delegation, trust) }\end{array}$ & $\begin{array}{l}\text { Network leadership } \\
\text { - External persuasive leadership } \\
\text { (rhetorical skills) } \\
\text { - Coalition network leadership } \\
\text { (coalition-building skills) }\end{array}$ \\
\hline & & \multicolumn{2}{|c|}{ Resilient leadership } \\
\hline & \multirow[t]{2}{*}{$\begin{array}{l}\text { Coercion } \\
\text { (regulation) }\end{array}$} & $\begin{array}{l}\text { Transactional leadership } \\
\text { - Maintaining leadership } \\
\text { - Internal managerial leadership }\end{array}$ & $\begin{array}{l}\text { Regulatory leadership } \\
\text { - Designing legal infrastructure }\end{array}$ \\
\hline & & \multicolumn{2}{|c|}{ Terry's Conservatorship (Protection of Institutional Autonomy) } \\
\hline
\end{tabular}

The internal and external loci of institutionalization distinguish leadership in(side) organizations from leadership of organizations. The former focuses on the internal dimension of institutionalization and attempts to develop a supporting mechanism involving internal constituents; the latter focuses on the external dimension of institution- 
alization and attempts to build a supporting mechanism involving external stakeholders.

The different mechanisms of institutionalization generate different styles of institutional leadership. Coercive institutionalization involves maintaining internal consistency through rewards and penalties and designing regulatory infrastructure to receive legitimacy from external stakeholders. Persuasive institutionalization arises from internal and external communication and co-optation. Normative or mimetic institutionalization involves transformational (charismatic, visionary) leadership and social constructive leadership.

Some styles of institutional leadership do not belong exclusively to one of these categories. Conservatorship interacts with both internal constituents and external stakeholders to protect distinctive values, competence, and roles. Resilient leadership allows for delegation and a learning process for internal constituents and more responsiveness for external stakeholders. Selznick's creative leadership is the art of institution building through coercive, normative, mimetic institutionalization, discovering strategies and skills to transform an organization into an institution, and interacting with internal constituents and external stakeholders (Selznick, 1957, pp. 149-154); Selznick's responsible leadership is a blend of understanding and commitment to set the identity of an institution and prevent it from drifting (Selznick, 1957, pp. 142-143).

\section{Exploring Components of Institutional Leadership}

We develop five types of institutional leadership by using factor analysis with 18 ministerial leadership questions. All questions were measured on a seven-point scale. A principal components factor analysis with varimax rotation was employed. ${ }^{8}$

Five factors of institutional leadership were identified on the basis of percentage of variance accounted for and uniqueness of defining variables: visionary leadership, persuasive leadership, resilient leadership, coalition network leadership, and maintaining leadership. Cumulative percentage of variance accounted for is 77.76 percent in the 18 leadership items. Table 1 reports a Cronbach's alpha indicating internal consistency reliability among combined items and the pattern of factor loading for the five retained factors. The primary factor of institutional leadership that emerged, accounting for

8. Orthogonal methods are most widely used, although the oblique rotation is more flexible and more realistic, since important underlying dimensions are not necessarily uncorrelated. The factors are rotated according to an orthogonal rotation method (varimax in SAS). Factor loadings greater than 0.60 are bolded. We also report Kaiser's measure of sampling adequacy (MSA), both overall and for the individual variables. Overall MSA is 0.93. In general, MSA values greater than 0.8 are considered good, while values less than 0.5 are unacceptable. 
22.15 percent of the variance in the 18 leadership items, is labeled visionary leadership. This consists of five ministerial leadership behaviors: providing new visions; providing new ideas; providing a new approach; signaling predictive rewards for accomplished goals; and coaching principles and methods. In our study, it has a Cronbach's alpha of 0.91 .

Table 1. Factor Analysis Results for the Leadership Profile ( $\mathrm{N}=542)$

\begin{tabular}{|c|c|c|c|c|c|}
\hline & Factor 1 & Factor 2 & Factor 3 & Factor 4 & Factor 5 \\
\hline Item 1: Providing new visions & 0.786 & 0.322 & 0.216 & 0.178 & 0.053 \\
\hline Item 2: Providing new ideas & 0.808 & 0.257 & 0.192 & 0.221 & -0.039 \\
\hline Item 3: Providing a new approach & 0.757 & 0.362 & 0.196 & 0.182 & 0.086 \\
\hline $\begin{array}{l}\text { Item 4: Signaling predictive rewards for accomplished } \\
\text { goals }\end{array}$ & 0.662 & 0.377 & 0.193 & 0.217 & 0.032 \\
\hline Item 5: Designing principles and rules & 0.615 & 0.207 & 0.464 & 0.146 & 0.245 \\
\hline $\begin{array}{l}\text { Item 6: Persuading cabinet members to support the } \\
\text { department's position }\end{array}$ & 0.371 & 0.765 & 0.240 & 0.258 & 0.002 \\
\hline $\begin{array}{l}\text { Item 7: Persuading the legislature to support the } \\
\text { department's position }\end{array}$ & 0.351 & 0.822 & 0.226 & 0.213 & 0.084 \\
\hline $\begin{array}{l}\text { Item 8: Persuading the media to support the } \\
\text { department's position }\end{array}$ & 0.408 & 0.752 & 0.254 & 0.252 & 0.068 \\
\hline $\begin{array}{l}\text { Item 9: Persuading interest groups and NGOs to } \\
\text { support the department's position }\end{array}$ & 0.328 & 0.718 & 0.292 & 0.216 & 0.085 \\
\hline Item 10: Being responsive to public opinion & 0.054 & 0.243 & 0.657 & 0.302 & 0.161 \\
\hline Item 11: Providing autonomy and slack & 0.369 & 0.263 & 0.737 & 0.171 & -0.023 \\
\hline $\begin{array}{l}\text { Item 12: Taking risks involving the department's } \\
\text { programs and projects }\end{array}$ & 0.529 & 0.289 & 0.576 & 0.207 & -0.019 \\
\hline Item 13: Encouraging communication & 0.418 & 0.214 & 0.695 & 0.183 & 0.081 \\
\hline $\begin{array}{l}\text { Item 14: Fostering a cooperative relationship with } \\
\text { the presidential chief of staff }\end{array}$ & 0.237 & 0.207 & 0.169 & 0.868 & -0.026 \\
\hline $\begin{array}{l}\text { Item 15: Fostering cooperative relationships with } \\
\text { presidential advisors }\end{array}$ & 0.180 & 0.204 & 0.211 & 0.898 & 0.006 \\
\hline $\begin{array}{l}\text { Item 16: Fostering cooperative relationships with } \\
\text { other departments }\end{array}$ & 0.319 & 0.374 & 0.263 & 0.612 & 0.143 \\
\hline Item 17: Avoiding change when everything works well & 0.017 & -0.018 & -0.086 & 0.050 & 0.889 \\
\hline $\begin{array}{l}\text { Item 18: Concentrating on tasks that previous } \\
\text { ministers have designed }\end{array}$ & 0.095 & 0.167 & 0.391 & -0.029 & 0.684 \\
\hline Eigenvalues & 3.99 & 3.34 & 2.72 & 2.54 & 1.40 \\
\hline Explained variance (\%) & 22.15 & 18.56 & 15.14 & 14.11 & 7.80 \\
\hline
\end{tabular}

Note: Explained variance is after varimax rotation. Factor $1=$ visionary leadership (Cronbach's alpha=0.91); factor 2 = persuasive leadership (Cronbach's alpha $=0.94$ ); factor $3=$ resilient leadership (Cronbach's alpha $=0.85$ ); factor $4=$ coalition network leadership (Cronbach's alpha=0.89); factor $5=$ maintaining leadership (Cronbach's alpha $=0.51$ ). Overall MSA $=0.93$. 
The second distinct factor of institutional leadership involves persuasive components, accounting for 18.56 percent of the variance. This is called persuasive leadership and consists of four ministerial leadership behaviors: (1) persuading cabinet members to support the department's position; (2) persuading the legislature to support the department's position; (3) persuading the media to support the department's position; and (4) persuading interest groups and NGOs to support the department's position. It has a Cronbach's alpha of 0.94 .

The third factor of institutional leadership is defined as resilient leadership, with 15.14 percent of the variance. This factor is derived from four ministerial leadership behaviors: (1) responding to public opinion; (2) providing autonomy and slack; (3) taking risks involving the department's programs and projects; and (4) encouraging communication. The resilient leadership measure displayed a Cronbach's alpha coefficient of 0.85 .

The fourth factor is defined as coalition network leadership, accounting for 14.11 percent of the variance. This factor consists of three items: (1) fostering a cooperative relationship with the presidential chief of staff; (2) fostering a cooperative relationship with presidential advisors; and (3) fostering a cooperative relationship with other departments. These components of network leadership focus on the relationship between the minister's department and the presidential office and the other departments. This scale has a Cronbach's alpha of 0.89 .

The fifth factor, accounting for 7.8 percent of the variance, consists of two items: avoiding change when everything is working well, and concentrating on tasks that previous ministers have designed and programmed. This factor is called maintaining leadership and measures ministerial leadership behaviors that protect and reaffirm traditional projects. In our study, it has a Cronbach's alpha of 0.51.

\section{Developing Hypotheses: The Relationship between Institutional Leadership Style and Leader's Performance}

Despite negative views of the impact of leadership, ${ }^{9}$ numerous studies have reported that leadership makes a difference in government (Dumdum, Lowe, \& Avolio, 2002; Lowe, Galen Kroeck, \& Sivasubramaniam, 1996; Trottier, Van Wart, \& Wang, 2008;

9. Some studies have argued that leadership is marginal and its effects are likely to be overstated (Pfeffer, 1977; Pfeffer \& Sutton, 2006, 192-193). Pfeffer (1977) found that leaders in private organizations most often explain no more than 10 percent of performance differences between the best and the worst organizations and teams. Kaufman (1981) argues that six top executives in the US federal government have had little influence on their organization's direction and their performance is modest and incremental. 
Wofford, Whittington, \& Goodwin, 2001; Egri \& Herman, 2000).

Previous case studies have established that institutional leaders can build and enhance the goals and integrity of public institutions (Doig and Hargrove, 1987; Lewis, 1984; Selznick, 1957). Most cases from these studies are examples of leaders who successfully institutionalized their organizations. Successful institutionalization is not a matter of happenstance but the function of effective institutional leadership (Kimberley, 1980; Selznick, 1957; Wilson, 1989).

However, little research has empirically investigated the relationship of institutional leadership to its effectiveness. In order to address these limitations and empirically test which components of institutional leadership are related to a leader's performance, we will develop an integrative empirical framework of institutional leadership in public organizations. We will also address how the effectiveness of institutional leadership varies depending on presidential support and departmental performance. The following section presents a series of hypotheses regarding the elements of institutional leadership that are associated with perceived ministerial performance.

\section{Visionary Leadership}

Selznick (1957) provides two components of the visionary leadership that transforms an organization into an institution. The art of institution building requires critical decisions (leadership) such as the definition of the institutional mission and the institutional embodiment of purpose. Following Selznick (1957), Doig and Hargrove (1987) also emphasize that the central task of leadership is to infuse an organization with values and an institutional philosophy. They illustrate that successful institutional leaders identify new missions and programs for their organizations. ${ }^{10}$ Some components of visionary leadership, such as inspirational motivation and intellectual stimulation, derive from transformational leadership. Inspirational motivation makes clear how tasks fit into the vision for the organization's future by using symbolism and rhetoric. Intellectual stimulation encourages followers to define and redefine their emergent problems (Avolio, Bass, \& Jung, 1999; Bass \& Avolio, 1994). On the basis of this literature, we propose the following hypothesis:

Hypothesis 1: A visionary leadership style will be positively associated with perceived ministerial performance.

10. Doig and Hargrove (1987) describe exemplary US public leaders with a creative vision: David Lilienthal at the Tennessee Valley Authority, Austin Tobin at the Port Authority of New York, Nancy Hanks at the National Endowment for the Arts, Elmer Staats at the General Accounting Office, and Marriner Eccles in the Federal Reserve System. 


\section{Persuasive Leadership}

Top executive leadership is a relational process embedded in ambiguity and uncertainty. Public leadership involves politics, persuasion, and influence. Successful leadership is often defined as a form of successful persuasion without coercion (Bass, 1990, p. 14). Persuasion is one form of leadership (Bass, 1990, p. 15) and includes rhetorical skills with emotional and rational attractiveness. Neustadt (1960) suggests that presidential leadership stems from the power to persuade. Doig and Hargrove (1987) illustrate that rhetorical leadership with the evocation of symbols promotes political resources and galvanizes public support. On the basis of this literature, we propose the following hypothesis:

Hypothesis 2: A persuasive leadership style will be positively associated with perceived ministerial performance.

\section{Resilient Leadership}

The concept of resilience can be defined as the capacity to adapt to and recover from conditions of enormous stress such as a disaster (Coutu, 2002; Mallak, 1998). Public organizations are increasingly vulnerable to their volatile environments (Boin $\&$ Christensen, 2008). Components of resilient leadership enable government organizations to sustain a competitive advantage through excellent performance and responsiveness to turbulent environments. Nonet and Selznick (1996) reveal that a responsive administration involves the broad delegation of authority, communication, and deep values and beliefs. In order to promote successful adaptive and learning systems, resilient leadership generates effective institutional characteristics (such as responsibility, multiple perspectives, and autonomy). It enables organizations to identify the most effective and efficient way of accomplishing complex and conflicting goals. It provides an opportunity to test a variety of practices with slack and a high tolerance of the risk of unexpected failures. It also emphasizes talking to and listening to external stakeholders (Boin \& Christensen, 2008). The above arguments suggest the following hypothesis:

Hypothesis 3: A resilient leadership style will be positively associated with perceived ministerial performance.

\section{Coalition Network Leadership}

Coalition network leadership is based on coalition-building processes. It is the strategic use of institutional ties to demonstrate the organization's worthiness and acceptability to external constituents. Selznick (1949) argues that public organizations 
that are dependent on gaining legitimacy from their constituencies will absorb new elements into their leadership as a means of averting threats to their stability or existence. He describes how outside interests are coopted by the organization and persuaded to support its projects. The intended effect of cooptation is to neutralize institutional opposition and enhance legitimacy. A good example is David Lilienthal's leadership of the Tennessee Valley Authority in the 1930s. Lilienthal faced many constituent groups that had opposed the formation of the Authority. He co-opted constituents largely by inviting them to join the many boards and committees within the organization. The above arguments suggest the following hypothesis:

Hypothesis 4: A coalition network leadership style will be positively associated with perceived ministerial performance.

\section{Maintaining Leadership}

Terry (1995) argues that the purpose of conservatorship is to protect institutional autonomy and integrity. The core responsibility of administrative leaders is to ensure the persistence of an organization's distinctive values, competence, and role. According to Terry (1995), administrative conservatorship is a maintenance leadership for the protection of public bureaucracies as valuable societal institutions. The maintaining style of leadership involves conserving mission, values, and support. It is concerned primarily with incremental change through fine-tuning and adaptive institutionalization.

Hypothesis 5: A maintaining leadership style will be positively associated with perceived ministerial performance.

\section{Interactions between Presidential Support, Performance Crisis, and Institutional Leadership}

Presidents do influence top executives, such as cabinet secretaries, through positive or negative signals. ${ }^{11}$ A positive signal enables the executive to implement agency missions and goals even though he or she might have limited resources to do so. It also enhances agency commitment and morale. In contrast, a negative presidential signal

11. Doig and Hargrove (1987) provide several examples of the importance of presidential support for successful institutionalization in US federal agencies. For instance, Franklin Roosevelt was a consistent supporter of David Lilienthal (director of the Tennessee Valley Authority), and Presidents Kennedy and Johnson's support was vital for the success of Robert McNamara (secretary of defense) and James Webb (administrator of the National Aeronautics and Space Administration). President Nixon strongly supported Nancy Hanks (chair of the National Endowment for the Arts). 
constrains the leadership capacity of top executives. Reduced presidential support demands more visionary leadership to provide a clear direction and vision to ensure the steady flow of political resources. A negative presidential signal would also require more persuasive and coalition network leadership. The competence of institutional leadership may largely depend on the level of presidential support. However, little research has focused on the interaction between institutional leadership and political support or pressures from external stakeholders. Thus we propose the following hypothesis:

Hypothesis 6a: The effectiveness of institutional leadership (visionary, persuasive, resilient, coalition network, and maintaining) will be related to the level of presidential support.

Leadership and organizational performance crises are closely intertwined phenomena (Boin \& 't Hart, 2003). Performance crises in organizations create a window of opportunity to reform institutional characteristics. A crisis also provides learning opportunities, attracting resilient leadership that responds to victims with care. Visionary leadership will be more necessary to provide clear direction to crisis management. Especially under conditions of crisis, visionary leadership can generate a higher level of follower motivation and commitment. Persuasive leadership is necessary to convince multiple external stakeholders (Boin \& 't Hart, 2003, p. 550). In addition, crisis management should minimize the damage to institutional integrity and rebuild it. This requires maintaining leadership to reaffirm existing structures and missions (Boin \& 't Hart, 2003 , p. 549). In an attempt to empirically test these relationships, we propose the following hypothesis:

Hypothesis 6b: The effectiveness of institutional leadership (visionary, persuasive, resilient, coalition network, and maintaining) will be related to whether there is a crisis of organizational performance.

\section{DATA AND EMPIRICAL MODEL}

\section{Sample and Data Collection}

The data for this study were collected by the second Korean Minister Survey of the Korean Civil Service Commission from December 2007 to January 2008. ${ }^{12}$ The

12. The first Korean Minister Survey of the Korean Civil Service Commission was conducted 
survey was conducted via mail; respondents were upper middle managers (equivalent to General Schedule 13-15 of the United States) and senior managers (equivalent to Executive Schedule 5-1 of the United States) from 13 departments of the South Korean government. Respondents were asked to evaluate their ministers' leadership styles and performances. This study did not include the ministries of National Defense, Unification, Education and Human Resources Development, Information and Communication, Construction and Transportation, or Gender Equality. ${ }^{13}$ The respondents were mainly civil servants no higher than grade 5 , who could easily identify ministerial leadership styles. ${ }^{14}$

The 2007 Korean Minister Survey was sent by mail to 1,024 civil servants in 13 departments. Of those surveys, 554 were returned (54.1 percent). We excluded 12 incomplete responses, leaving a total of 542. Table 2 shows the number participants by ministry.

from April to May 2002 and consisted of 22 items regarding ministerial leadership style (Jung, Moon, \& Hahm, 2008).

13. The period of the survey involved many problems stemming from a radical government reorganization. In January 2008, president-elect Lee Myung-bak's transition committee tried to downsize the executive branch of the Rho Moo-hyun administration from 18 ministries to 13,22 sub-ministry organizations to 19 , and 10 committees to 5 . However, there was strong resistance from both the opposition party and president Rho. The National Assembly approved trimming the government to 16 ministries; this was accomplished through consolidation and mergers of existing ministries. For instance, the Ministry of Human Resources and Science combined the operations of the Ministry of Education and Human Resources Development and the Ministry of Science and Technology. The Ministry of Health, Welfare, and Family Affairs assumed the functions of the former Ministry of Gender Equality. The Ministry of Land, Transport, and Maritime Affairs assumed the main functions of the Ministry of Maritime Affairs and Fisheries. The Ministry of Policy Coordination resulted from the merger of the ministries of Finance and Economy and Strategic Planning and Budget. Both the Ministry of Maritime Affairs and Fisheries and the Ministry of Information and Communication were closed. The transition committee proposed merging the functions of the Ministry of Unification into the Ministry of Foreign Affairs and Trade, but the Unification Ministry was retained.

14. Although those below grade 6 make up a much higher proportion of the national government civil service, they are relatively much less selected than their actual proportion. They usually have much less contact with their minister than civil servants at grades higher than 5. In September 30, 2007, the number of civil servants for each grade in national government was as follows: 1,462 for grades $1-3 ; 5,116$ for grade $4 ; 11,326$ for grade $5 ; 22,568$ for grade $6 ; 25,179$ for grade $7 ; 16,139$ for grade 8 ; and 8, 953 for grade 9. 
Table 2. Survey Participants by Ministry

\begin{tabular}{|c|c|c|}
\hline & Number & Percent \\
\hline \multicolumn{3}{|l|}{ Ministry } \\
\hline Government Administration and Home Affairs & 43 & 7.76 \\
\hline Health and Welfare & 36 & 6.50 \\
\hline Finance and Economy & 52 & 9.39 \\
\hline Environment & 60 & 10.83 \\
\hline Culture and Tourism & 30 & 5.42 \\
\hline Science and Technology & 44 & 7.94 \\
\hline Commerce, Industry, and Energy & 45 & 8.12 \\
\hline Planning and Budget & 60 & 10.83 \\
\hline Construction and Transportation & 38 & 6.86 \\
\hline Labor & 17 & 3.07 \\
\hline Justice & 43 & 7.76 \\
\hline Maritime Affairs and Fisheries & 38 & 6.86 \\
\hline Foreign Affairs and Trade & 48 & 8.66 \\
\hline \multicolumn{3}{|l|}{ Gender (missing = 1) } \\
\hline Male & 515 & 93.13 \\
\hline Female & 38 & 6.87 \\
\hline \multicolumn{3}{|l|}{ Grade (missing = 5) } \\
\hline Above grade 3 & 30 & 5.46 \\
\hline Grade 4 & 198 & 36.07 \\
\hline Grade 5 & 234 & 42.62 \\
\hline Below grade 6 & 87 & 15.85 \\
\hline Total & 554 & $100 \%$ \\
\hline
\end{tabular}

\section{Analytical Model of Institutional Leadership and Ministerial Performance}

In this study, ministerial performance is hypothesized to vary across different types of institutional leadership. This relationship is hypothesized to interact with presidential support and the presence of a performance crisis in the department. The analytical model in this study is shown in figure 2. 
Figure 2. Effects of Institutional Leadership on Perceived Performance

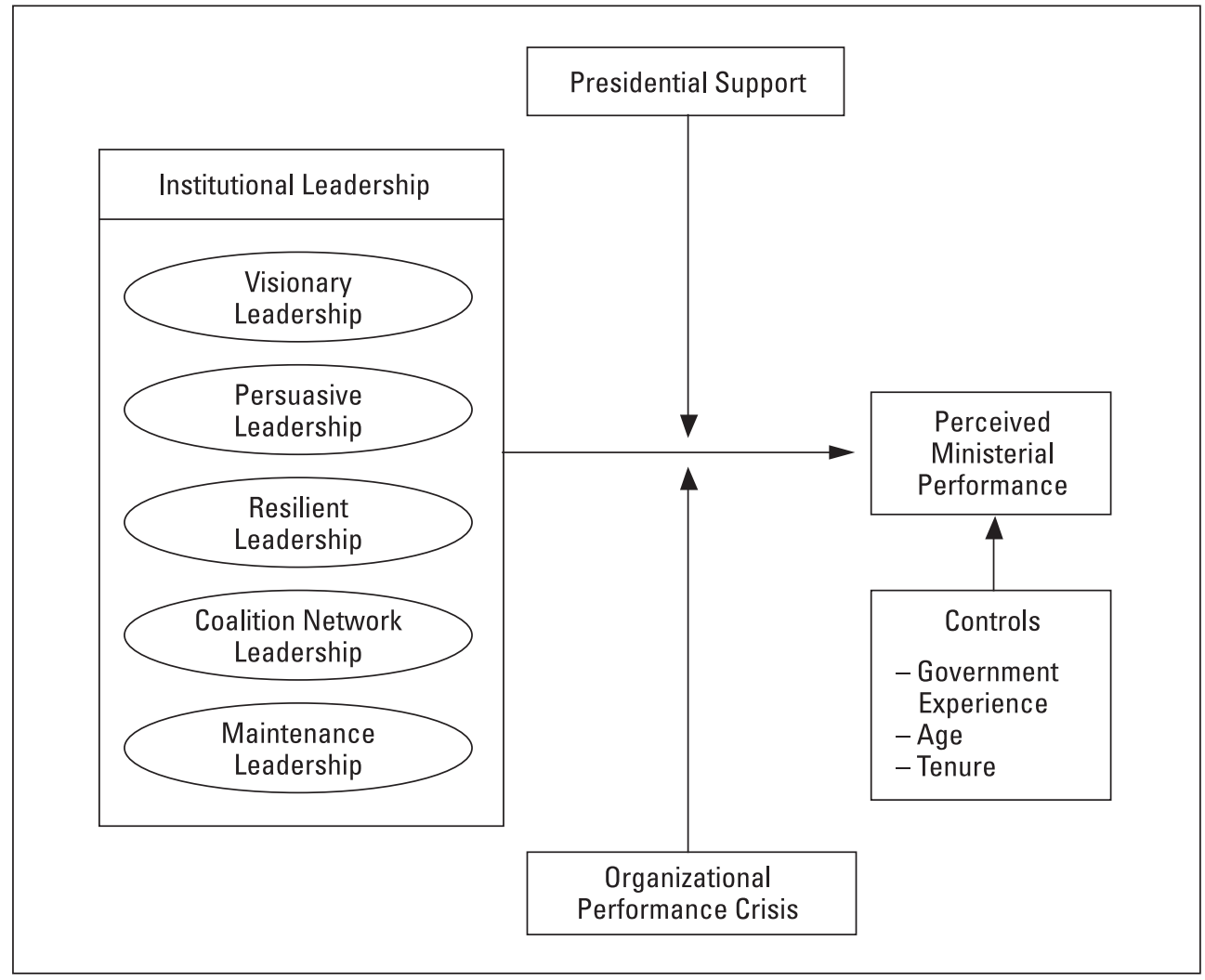

The empirical model of the effects of institutional leadership developed and tested in the study is shown below.

$$
\begin{aligned}
& \text { Empirical Model of Institutional Leadership } \\
& \begin{aligned}
\mathrm{P}_{i}= & \alpha+\beta_{1} \mathrm{~L}_{1 i}+\beta_{2} \mathrm{~L}_{2 i}+\beta_{3} \mathrm{~L}_{3 i}+\beta_{4} \mathrm{~L}_{4 i}+\beta_{5} \mathrm{~L}_{5 i}+\beta_{6} \mathrm{Bureau}_{i}+\beta_{7} \mathrm{Age}_{i} \\
& +\beta_{8} \mathrm{Tenure}_{i}+\theta_{1} \mathrm{PC}_{i}+\theta_{2} \mathrm{TOC}_{i}+\theta_{11} \mathrm{PC}_{i} \times \mathrm{L}_{1 i}+\theta_{12} \mathrm{PC}_{i} \times \mathrm{L}_{i} \\
& +\theta_{13} \mathrm{PC}_{i} \times \mathrm{L}_{3 i}+\theta_{14} \mathrm{PC}_{i} \times \mathrm{L}_{4 i}+\theta_{15} \mathrm{PC}_{i} \times \mathrm{L}_{5 i}+\theta_{21} \mathrm{COC}_{i} \times \mathrm{L}_{1 i} \\
& +\theta_{22} \mathrm{COC}_{i} \times \mathrm{L}_{2 i}+\theta_{23} \mathrm{COC}_{i} \times \mathrm{L}_{3 i}+\theta_{24} \mathrm{COC}_{i} \times \mathrm{L}_{4 i}+\theta_{25} \mathrm{COC}_{i} \times \mathrm{L}_{5 i} \\
& +\varepsilon_{i} \\
\alpha= & \text { intercept } \\
i= & 1,2,3 \ldots 542 \text { (the total number of survey respondents used in the model) } \\
\mathrm{P}= & \text { perceived ministerial performance evaluated by civil servants: (1) overall } \\
& \text { perceived performance with a seven-point scale and (2) perceived policy }
\end{aligned}
\end{aligned}
$$


performance measured by the sum of policy design, policy implementation, and policy solution, each with a seven-point scale

$\mathrm{L}_{1}=$ visionary leadership; $\mathrm{L}_{2}=$ persuasive leadership; $\mathrm{L}_{3}=$ resilient leadership; $\mathrm{L}_{4}=$ coalition network leadership; $\mathrm{L}_{5}=$ maintaining leadership

Bureau $=$ government experience $($ yes $=1$, no $=0)$; Age $=$ minister's age; Tenure $=$ minister's tenure (months)

$\mathrm{PC}=$ presidential support with a seven-point scale ( $1=$ below average, $0=$ above average)

$\mathrm{COC}=$ threat (crisis of organizational capacity) with a seven-point scale $(1=$ above average, $0=$ below average)

$\varepsilon=$ error terms

\section{Measures}

\section{Ministerial Performance}

The variable of ministerial performance was assessed by the minister's employees using two measures: (1) overall performance with a seven-point Likert-like scale and (2) policy capacity measured by the average performance of policy design, policy implementation, and solving policy problems. All three policy capacity measures are scored on Likert-like scales from 1 to 7 . The Cronbach's alpha of the three items is 0.93 in our study (see appendix).

\section{Institutional Leadership}

Five types of institutional leadership are measured by standardized factor scores. Their mean values are zero with one standard deviation.

\section{Weak Presidential Support and Crisis of Organizational Performance}

Presidential support is measured as a minister's degree of presidential trust. The variable of presidential support is captured on a seven-point scale from very low to very high and is evaluated by government bureaucrats. In this study, presidential support is a dummy variable coded as 1 below average. Crisis of organizational performance is measured as the degree to which departments are criticized by public opinion and the media when ministers start their jobs in their departments. The performance crisis measure is evaluated by followers and the dummy variable coded as 1 above average.

\section{Control Variables}

Three measures of a minister's background are included as control variables in the study: prior experience in government, age, and tenure. Leaders with extensive govern- 
ment experience are expected to effectively change and maintain institutional structures and practices. Ministers with a longer tenure are likely to perform better than ministers with a short tenure.

\section{EMPIRICAL RESULTS AND DISCUSSION}

\section{Relationship between Institutional Leadership and Performance}

In the first part of the analysis, we undertake correlation analysis in order to identify the relationship between institutional leadership and ministerial performance. Table 3 shows the bivariate correlation matrix. Correlations between institutional leadership and ministerial performance reveal strong relations between some of the institutional leadership factors. For instance, overall perceived ministerial performance correlates 0.536 with visionary leadership, 0.537 with persuasive leadership, 0.359 with resilient leadership, and 0.214 with coalition network leadership. All of these correlations are statistically significant ( $\mathrm{p}$-values $<0.001$ ). However, overall perceived performance correlates weakly $(0.088)$ with maintaining leadership.

Table 3. Bivariate Correlations between Institutional Leadership and Performance

\begin{tabular}{l|c|c}
\hline \multirow{2}{*}{ Dependent variables } & \multicolumn{2}{|c}{ Independent variables } \\
\cline { 2 - 3 } & $\begin{array}{c}Y_{1} \text { (overall perceived } \\
\text { performance) }\end{array}$ & $\begin{array}{c}Y_{2} \text { (perceived policy } \\
\text { performance) }\end{array}$ \\
\hline Visionary leadership (factor 1) & $0.536^{* * *}$ & $0.630^{* * *}$ \\
\hline Persuasive leadership (factor 2) & $0.537^{* * *}$ & $0.439^{* * *}$ \\
\hline Resilient leadership (factor 3) & $0.359^{* * *}$ & $0.259^{* * *}$ \\
\hline Coalition network leadership (factor 4) & $0.214^{* * *}$ & $0.243^{* * *}$ \\
\hline Maintaining leadership (factor 5) & $0.088^{*}$ & 0.058 \\
\hline Bureau & $0.102^{*}$ & $0.182^{* * *}$ \\
\hline Age & $0.236^{* * *}$ & $0.228^{* * *}$ \\
\hline Tenure (months) & $0.159^{* * *}$ & $0.145^{* * *}$ \\
\hline Presid (dummy) & $-0.462^{* * *}$ & $-0.463^{* * *}$ \\
\hline Threat (dummy) & $-0.127^{* *}$ & $-0.159^{* *}$ \\
\hline Presid ${ }^{*}$ factor 1 & $0.430^{* * *}$ & $0.481^{* * *}$ \\
\hline Presid * factor 2 & $0.406^{* * *}$ & $0.363^{* * *}$ \\
\hline Presid * factor 3 & $0.247^{* * *}$ & $0.166^{* * *}$ \\
\hline Presid * factor 4 & $0.226^{* * *}$ & $0.233^{* * *}$ \\
\hline
\end{tabular}




\begin{tabular}{l|c|c}
\hline \multirow{2}{*}{ Dependent variables } & \multicolumn{2}{|c}{ Independent variables } \\
\cline { 2 - 3 } & $\begin{array}{c}Y_{1} \text { (overall perceived } \\
\text { performance) }\end{array}$ & $\begin{array}{c}Y_{2} \text { (perceived policy } \\
\text { performance) }\end{array}$ \\
\hline Presid ${ }^{*}$ factor 5 & $0.088^{*}$ & $0.102^{*}$ \\
\hline Threat ${ }^{*}$ factor 1 & $0.400^{* * *}$ & $0.478^{* * *}$ \\
\hline Threat ${ }^{*}$ factor 2 & $0.390^{* * *}$ & $0.327^{* * *}$ \\
\hline Threat ${ }^{*}$ factor 3 & $0.272^{* * *}$ & $0.172^{* * *}$ \\
\hline Threat ${ }^{*}$ factor 4 & $0.184^{* * *}$ & $0.207^{* * *}$ \\
\hline Threat ${ }^{*}$ factor 5 & $0.090^{*}$ & $0.077^{*}$ \\
\hline
\end{tabular}

Presid = presidential support; threat $=$ performance crisis.

${ }^{*} p<0.05$

$* * p<0.01$

$* * * \mathrm{p}<0.001$

The correlations between institutional leadership and ministerial policy capacity display similar patterns to those between institutional leadership and overall perceived ministerial performance. Visionary leadership correlates more with ministerial policy capacity $(r=0.63)$ than with overall perceived ministerial performance $(r=0.536)$. Maintaining leadership does not correlate with ministerial policy capacity. All of the control variables - government experience, age, and tenure-positively correlate with ministerial performance. In sum, visionary leadership and persuasive leadership correlate more strongly with perceived ministerial performance than the other institutional leadership components do.

\section{Regression Results}

In order to test the study hypotheses, two measures of perceived ministerial performance are regressed onto the five institutional leadership factors, while controlling for several characteristics of the ministers (government experience, age, and tenure) and departmental contexts (presidential support and performance crisis). The results of ordinary least squares analysis indicate that together with the controls, the five institutional leadership factors explain about 76.9 percent of the variance in overall perceived ministerial performance and about 73.5 percent of the variance in perceived ministerial policy capacity.

However, the relative effects of the five institutional leadership factors are different. As the above correlation analyses show, visionary leadership and persuasive leadership appear to have the most powerful impact on ministerial performance. The effect of visionary leadership is the greatest on ministerial policy performance; the effect of persuasive leadership is the greatest on overall perceived ministerial leadership. Fol- 
lowing these, both resilient leadership and coalition network leadership also have a significant effect on ministerial performance. However, maintaining leadership has little or no significant effect on ministerial performance. These findings are described in more detail in tables 4 and 5.

Table 4. Regression Results (Dependent Variable = Overall Perceived Performance)

\begin{tabular}{|c|c|c|c|c|}
\hline \multirow[b]{2}{*}{ Independent variables } & \multicolumn{2}{|l|}{ Model 1-1 } & \multicolumn{2}{|l|}{ Model 1-2 } \\
\hline & $\begin{array}{l}\text { Unstandardized } \\
\text { regression coefficients }\end{array}$ & Beta & $\begin{array}{l}\text { Unstandardized } \\
\text { regression coefficients }\end{array}$ & Beta \\
\hline Intercept & $3.869(0.412)^{* *}$ & & $3.764(0.407)^{* *}$ & \\
\hline Visionary leadership (factor 1) & $0.682(0.032)^{* *}$ & 0.494 & $0.551(0.053)^{* *}$ & 0.400 \\
\hline Persuasive leadership (factor 2) & $0.696(0.03)^{* *}$ & 0.505 & $0.635(0.052)^{* *}$ & 0.460 \\
\hline Resilient leadership (factor 3) & $0.483(0.029)^{* *}$ & 0.350 & $0.353(0.050)^{* *}$ & 0.256 \\
\hline Coalition network leadership (factor 4) & $0.221(0.038)^{* *}$ & 0.160 & $0.134(0.065)^{*}$ & 0.097 \\
\hline Maintaining leadership (factor 5) & $0.105(0.029)^{* *}$ & 0.076 & $0.018(0.048)$ & 0.013 \\
\hline Bureau & $0.080(0.062)$ & 0.029 & $0.058(0.061)$ & 0.021 \\
\hline Age & $0.020(0.007)^{* *}$ & 0.064 & $0.024(0.007)^{* *}$ & 0.076 \\
\hline Tenure & $0.00026(0.00018)$ & 0.033 & $0.00021(0.00018)$ & 0.027 \\
\hline Presid (dummy) & $-0.251(0.083)^{* *}$ & -0.091 & $-0.224(0.082)^{* *}$ & -0.081 \\
\hline Threat (dummy) & $-0.018(0.058)$ & -0.007 & $-0.024(0.057)$ & -0.009 \\
\hline Presid * factor 1 & & & $0.250(0.061)^{* *}$ & 0.114 \\
\hline Presid * factor 2 & & & $0.157\left(0.060^{* *}\right.$ & 0.081 \\
\hline Presid * factor 3 & & & $0.144(0.059)^{*}$ & 0.069 \\
\hline Presid * factor 4 & & & $0.133(0.075)$ & 0.064 \\
\hline Presid * factor 5 & & & $-0.086(0.065)$ & -0.032 \\
\hline Threat * factor 1 & & & $0.052(0.057)$ & 0.029 \\
\hline Threat * factor 2 & & & $-0.012(0.059)$ & -0.007 \\
\hline Threat * factor 3 & & & $0.117(0.059)^{*}$ & 0.065 \\
\hline Threat * factor 4 & & & $0.028(0.058)$ & 0.016 \\
\hline \multirow[t]{2}{*}{ Threat* factor 5} & & & $0.157(0.058)^{* *}$ & 0.089 \\
\hline & \multicolumn{2}{|l|}{$R^{2}=0.769$} & \multicolumn{2}{|l|}{$R^{2}=0.786$} \\
\hline
\end{tabular}

Note: Standard errors in parentheses. Beta represents the standardized regression coefficients.

Presid $=$ presidential support; threat $=$ performance crisis .

${ }^{*} \mathrm{p}<0.05$

${ }^{* *} \mathrm{p}<0.01$ 
Table 5. Regression Results (Dependent Variable = Perceived Policy Performance)

\begin{tabular}{|c|c|c|c|c|}
\hline \multirow[b]{2}{*}{ Independent variables } & \multicolumn{2}{|l|}{ Model 2-1 } & \multicolumn{2}{|l|}{ Model 2-2 } \\
\hline & $\begin{array}{l}\text { Unstandardized } \\
\text { regression coefficients }\end{array}$ & Beta & $\begin{array}{l}\text { Unstandardized } \\
\text { regression coefficients }\end{array}$ & Beta \\
\hline Intercept & $12.122(1.232)^{* *}$ & & $11.556(1.23)^{* *}$ & \\
\hline Visionary leadership (factor 1) & $2.235(0.096)^{* *}$ & 0.580 & $1.933(0.159)^{* *}$ & 0.502 \\
\hline Persuasive leadership (factor 2) & $1.568(0.091)^{* *}$ & 0.407 & $1.282(0.158)^{* *}$ & 0.333 \\
\hline Resilient leadership (factor 3) & $0.997(0.089)^{* *}$ & 0.259 & $0.854(0.151)^{* *}$ & 0.222 \\
\hline Coalition network leadership (factor 4) & $0.778(0.115)^{* *}$ & 0.202 & $0.703(0.196)^{*}$ & 0.183 \\
\hline Maintaining leadership (factor 5) & $0.174(0.087)^{* *}$ & 0.045 & $-0.160(0.145)$ & -0.042 \\
\hline Bureau & $0.664(0.185)^{* *}$ & 0.086 & $0.539(0.184)^{* *}$ & 0.070 \\
\hline Age & $0.050(0.022)^{*}$ & 0.057 & $0.063(0.022)^{* *}$ & 0.071 \\
\hline Tenure & $-0.00045(0.0005)^{* *}$ & 0.020 & $0.0004(0.0005)$ & 0.022 \\
\hline Presid (dummy) & $-0.558(0.250)^{*}$ & -0.072 & $-0.496(0.247)^{*}$ & -0.064 \\
\hline Threat (dummy) & $-0.347(0.175)^{*}$ & -0.045 & $-0.373(0.172)^{*}$ & -0.048 \\
\hline Presid * factor 1 & & & $0.530(0.186)^{* *}$ & 0.114 \\
\hline Presid * factor 2 & & & $0.580(0.183)^{* *}$ & 0.086 \\
\hline Presid * factor 3 & & & $0.205(0.180)$ & 0.107 \\
\hline Presid * factor 4 & & & $-0.042(0.229)$ & 0.035 \\
\hline Presid * factor 5 & & & $0.0005(0.196)$ & -0.007 \\
\hline Threat * factor 1 & & & $0.172(0.173)$ & 0.00007 \\
\hline Threat * factor 2 & & & $-0.004(0.179)$ & -0.0007 \\
\hline Threat * factor 3 & & & $0.124(0.178)$ & 0.025 \\
\hline Threat ${ }^{*}$ factor 4 & & & $0.149(0.177)$ & 0.030 \\
\hline \multirow[t]{2}{*}{ Threat * factor 5} & & & $0.476(0.176)^{* *}$ & 0.097 \\
\hline & \multicolumn{2}{|l|}{$R^{2}=0.735$} & \multicolumn{2}{|l|}{$R^{2}=0.750$} \\
\hline
\end{tabular}

Note: Standard errors in parentheses. Beta represents the standardized regression coefficients.

Presid $=$ presidential support; threat $=$ performance crisis .

${ }^{*} \mathrm{p}<0.05$

${ }^{* *} p<0.01$

\section{Moderating Effects of Presidential Support and Performance Crisis}

We tested whether presidential support and performance crisis moderate the relationship between institutional leadership style and ministerial performance. We found several moderating effects, especially under conditions of low presidential support and high performance crisis.

First, the relationship between visionary leadership and overall perceived perfor- 
mance varies with different levels of presidential support. The slope of the relationship between visionary leadership and overall perceived performance is steeper under low presidential support. Figure 3 illustrates the significant interaction between presidential support and visionary leadership. In line with Hypothesis 6a, a strong relationship is evident between visionary leadership and presidential support. The effect of visionary leadership is stronger when presidential support is low. Presidential support also moderates the relationship between persuasive leadership and overall perceived performance. These moderating effects of presidential support are also found in the dependent variable of policy capacity. In sum, visionary leadership and persuasive leadership have more significant effects on ministerial performance, especially with a lower level of presidential support.

Figure 3. Moderating Effects of Presidential Support

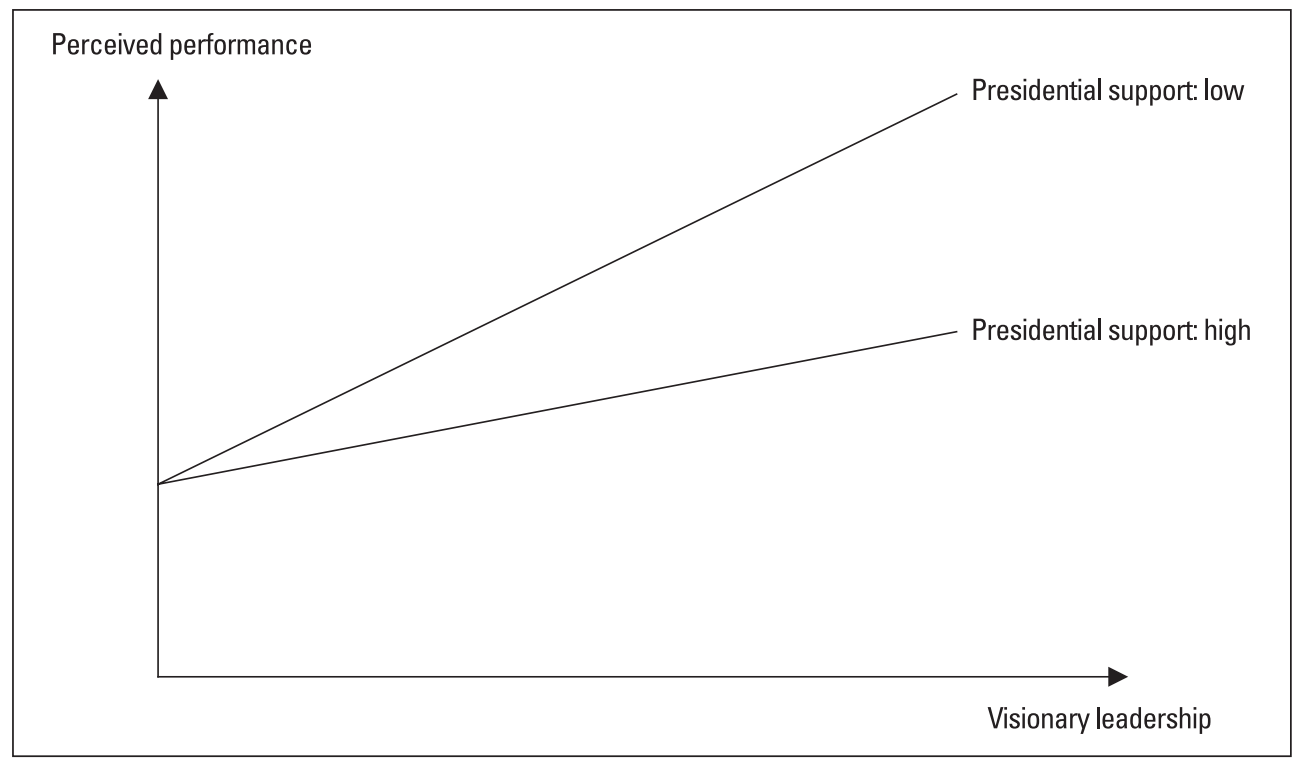

Second, performance crisis moderates the relationship between maintaining leadership and ministerial performance. As shown figure 4, the effect of maintaining leadership on ministerial performance depends on performance crisis. Maintaining leadership has a positive impact on ministerial performance under high performance crisis, but no impact when there is no performance crisis. Maintaining leadership is expected to enhance ministerial performance, especially when organizational performance is criticized by external stakeholders. 
Figure 4. Moderating Effects of Performance Crisis

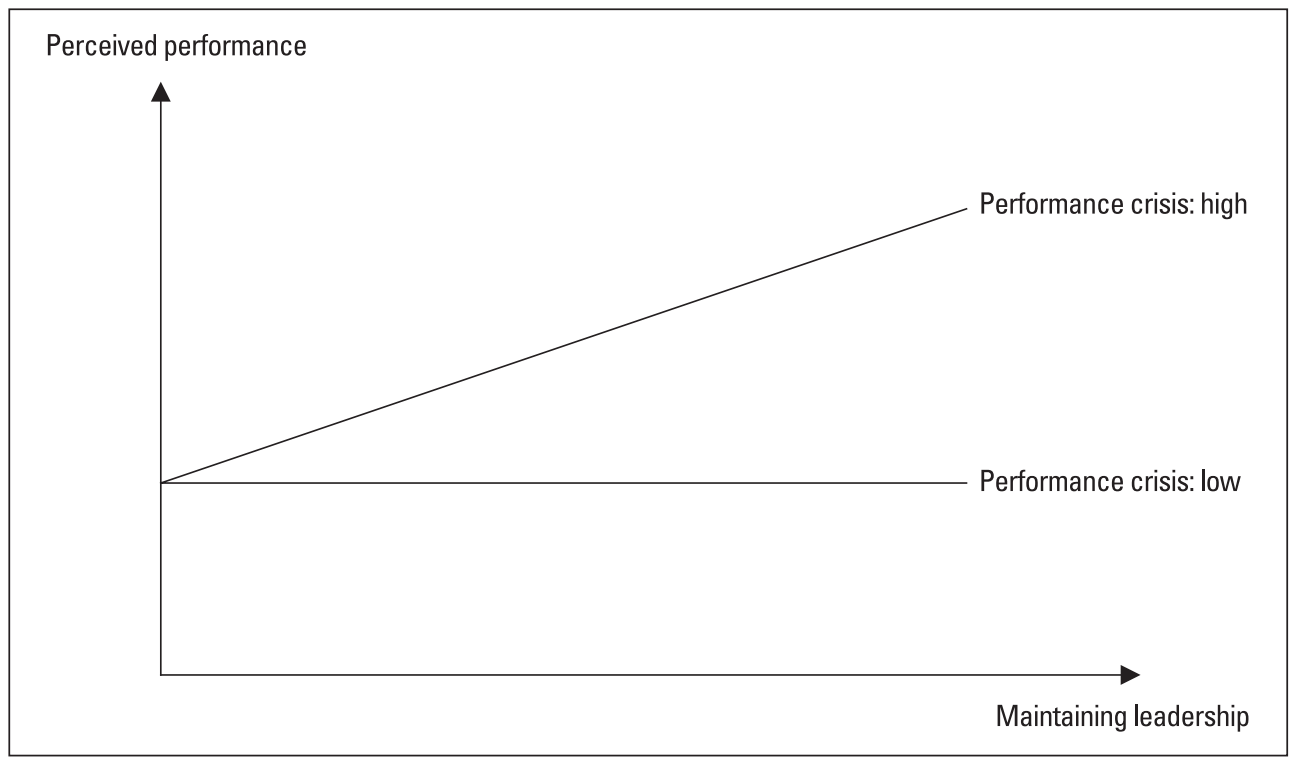

\section{CONCLUSIONS AND RECOMMENDATIONS FOR FURTHER STUDY}

This study examined key components of institutional leadership derived from an exploratory factor analysis and investigated the relationship between institutional leadership styles and ministers' perceived performance. We found five types of institutional leadership: visionary, persuasive, resilient, coalition network, and maintaining leadership. Doig and Hargrove (1987) describe six dimensions of leadership from 14 top executives in US federal agencies. These institutional leadership characteristics derived from US public organizations match those found in Korean public organizations. For instance, the first dimension, identifying new missions and programs for organizations using rhetorical skills, is similar to visionary leadership and persuasive leadership in our study; the second dimension, developing and nourishing external constituencies to support new goals and programs, and the third dimension, creating internal constituencies that support the new goals, are similar to coalition network leadership in our study; the fourth dimension, enhancing the organization's technical expertise, and the fifth dimension, motivating members of the organization, are associated with resilient leadership in our study. The sixth dimension, systematically scanning organizational routines and points of internal and external pressure, links to maintain- 
ing leadership in our study. These findings suggest that key components of institutional leadership in Korean and US public organizations are very similar.

We empirically investigated which types of institutional leadership are associated with ministers' perceived performance. We found that visionary leadership and persuasive leadership are primary determinants of ministers' performance. The next primary determinants are resilient leadership and coalition network leadership. However, maintaining leadership is not significantly associated with ministers' performance.

In addition, we found moderating effects of presidential support and performance crisis on the relationship between the five types of institutional leadership and ministers' performance. The effects of visionary leadership and persuasive leadership on ministers' performance are larger for ministers with low presidential support than for those with high presidential support. The effect of maintaining leadership on ministers' performance is found only when a performance crisis is serious.

Taken as a whole, this study suggests that institutional leadership consists of various dimensions within the tasks of creating, nourishing, and maintaining institutions. We find that rhetorical leadership (visionary leadership and persuasive leadership) is significantly associated with ministers' performance. Coalition-building skills (coalition network leadership) are also positively related to ministers' performance, but the association is less than that of rhetorical leadership. We find that resilient leadership is also positively associated with ministers' performance. This finding supports the hypothesis that "institutional builders facilitate trial-and-error processes in the pursuit of effective practices" (Boin \& Christensen, 2008, p. 282). However, although maintaining leadership is noted as the key function of institutional leadership (Selznick, 1957), its effect on ministers' performance is less than that of the other four types of institutional leadership. This finding suggests that conservative leadership to identify existing missions and programs is not associated positively with ministers' performance.

The limitations of this study mainly derive from problems with measurement of both institutional leadership and ministers' performance. One significant limitation is that ministers' performance is rated by their followers. This is likely to involve a common method variance (CMV) problem because bureaucrats rate simultaneously both the minister's performance as a dependent variable and its explanatory variables in the same survey questionnaire. This self-reported survey completed by Korean bureaucrats relies on single-source leadership data and outcome ratings. Such perceptual data from single raters can often generate the CMV bias (Posdsakoff, MacKenzie, Lee, \& Podsakoff, 2003; Change et al., 2010).

Respondents' biases for specific components of institutional leadership are likely to influence the relationship between institutional leadership and ministers' performance. For instance, if bureaucrats prefer maintaining leadership behaviors, they are 
more likely to highly evaluate ministers with this leadership style. Further study is required to control for this confounding factor from the CMV. The CMV problem can, by definition, be eliminated if the dependent variable of ministerial performance is constructed using measures from different sources other than the independent variables. The best way to avoid the likelihood of CMV is to generate different measures for different ministerial performance constructs from various sources.

Another limitation is the correlation nature of cross-sectional data that prohibits identifying a clear causal effect. In order to investigate causal effects of institutional leadership on performance, further research should extend to quasi-experiment-based data or longitudinal data. In addition, institutional leadership is expected to vary across different stages of institutionalization. A young organization may require institutional leadership to create new visions and missions. Further study is needed to investigate how institutional leadership matters across different stages of the institutionalization process.

\section{REFERENCES}

Andeweg, R. B. 2000. Ministers as double agents? The delegation process between cabinet and ministers. European Journal of Political Research, 37(3): 377-395.

Avolio, B. J., Bass, B. M., \& Jung, D. I. 1999. Re-examining the components of transformational and transactional leadership using the Multifactor Leadership Questionnaire. Journal of Occupational and Organizational Psychology, 72: 441-462.

Barnard, C. 1938. The Function of the Executive. Cambridge: Harvard University Press.

Bass, B. M. 1985. Leadership and performance beyond expectations. New York: Free Press.

1990. Handbook of leadership (3rd ed.). New York: Free Press.

Bass, B. M, \& Avolio, B. J. 1994. Improving organizational effectiveness through transformational leadership. Thousand Oaks, CA : Sage Publications.

Boin, A., \& Christensen, T. 2008. The development of public institutions: Reconsidering the role of leadership. Administration and Society, 40(3): 271-298.

Boin, A., \& 't Hart, P. 2003. Public leadership in times of crisis: Mission impossible? Public Administration Review, 63(5): 544-553.

Burns, J. M. 1978. Leadership. New York: Harper and Row.

Chabal, P. M. 2003. Do ministers matter? The individual style of ministers in programmed policy change. International Review of Administrative Science, 69: 
29-49.

Chang, S., van Witteloostuijn, A., \& Eden, L. 2010. From the editors: Common method variance in international business research. Journal of International Business Studies, 41: 178-184.

Christensen, S., Karnoe, P., Pedersen, J. S., \& Dobbin, F. 1997. Action in institutions. American Behavioral Scientist, 40: 389-538.

Coutu, D. L. 2002. How resilience works. Harvard Business Review, 80(5): 46-55.

Denis, J. L., Lamothe, L., \& Langley, A. 2001. The dynamics of collective leadership and strategic change in pluralistic organizations. Academy of Management Journal, 44(4): 809-837.

Denis, J. L., Langley, A., \& Rouleau, L. 2005. Rethinking leadership in public organizations. In E. Frlie, L. E. Lynn, \& C. Pollitt (eds.), The Oxford handbook of public management. New York: Oxford University Press.

DiMaggio, P. J. 1988. Interest and agency in institutional theory. In L. G. Zucker (ed.), Institutional patterns and organizations (pp. 3-21). Cambridge, MA: Ballinger.

Doig, J. W. \& Hargrove, E. C. (eds.). 1987. Leadership and innovation. Baltimore, MD: The Johns Hopkins University Press.

Dumdum, U. R., Lowe, K. B., \& Avolio, B. J. 2002. Meta-analysis of transformational and transactional leadership correlates of effectiveness and satisfaction: An update and extension. In B. J. Avolio and F. J. Yammarino (eds.), Transformational and charismatic leadership: The road ahead (pp. 35-65). New York: JAI Press.

Egri, C. P., \& Herman, S. 2000. Leadership in the North American environmental sector: Values, leadership styles, and contexts of environmental leaders and their organizations. Academy of Management Journal, 43: 571-604.

Fligstein, N. 1997. Social skill and institutional theory. American Behavioral Scientist, 40: 397-405.

Getha-Taylor, H., Holmes, M.H., Jacobson, W.S., Morse, R.S., \& Sowa, J.E. 2011. Focusing the Lens of Public Leadership: Research Propositions and Questions in the Minnowbrook Tradition. Journal of Public Administration Research and Theory, 21(Minnowbrook III: A special issue):i83-i97.

Jarzabkowski, P. 2003. Strategic practices: An activity theory perspective on continuity and change. Journal of Management Studies, 40(1): 23-56.

Jung, K., Moon, M. J., \& Hahm, S. D. 2008. Exploring the linkage between ministerial leadership and performance in Korea. Administration \& Society, 40(7): 667-690.

Kaufman, H. 1981. The administrative behavior of federal bureau chiefs. Washington, DC: Brookings Institution.

Kimberley, J. R. 1980. Initiation, innovation, and institutionalization in the creation process. In J. R. Kimberley \& R. H. Miles (eds.), The organizational life cycle: 
Issues in the creation, transformation, and decline of organizations (pp. 18-43). San Francisco: Jossey-Bass.

King, A. 1994. Ministerial autonomy in Britain. In M. Laver and K. A. Shepsle (eds.), Cabinet ministers and parliamentary government (pp. 203-225). New York: Cambridge University Press.

Lewis, E. 1984. Public entrepreneurship: Toward a theory of bureaucratic political power. Bloomington, IN: Indiana University Press.

Lowe, K. B., Galen Kroeck, K., \& Sivasubramaniam, N. 1996. Effectiveness correlates of transformational and transactional leadership: A meta-analytic review of the MLQ literature. The Leadership Quarterly, 7: 385-425.

Mallak, L. 1998. Putting organizational resilience to work. Industrial Management, 40(6): 8-13.

Marsh, D., Richards, D., \& Smith, M. J. 2000. Re-assessing the role of departmental cabinet ministers. Public Administration, 78(2): 305-326.

Mintzberg, H., \& McHugh, A. 1985. Strategy formation in an adhocracy. Administrative Science Quarterly, 24(4): 580-589.

Neustadt, R. 1960. Presidential power: The politics of leadership. New York: Wiley.

Nohria, N., \& Khurana, R. 2010. Handbook of Leadership Theory and Practice. Boston: Harvard Business Press.

Nonet, P., \& Selznick, P. 1996. Law and society in transition: Towards responsive law. New York: Octagon Books.

Nye, J. S., Jr. 2008. The power to lead. Oxford: Oxford University Press.

Pfeffer, J. 1977. The ambiguity of leadership. Academy of Management Review, 2: 104-112.

Pfeffer, J., \& Sutton, R. I. 2006. Hard facts, dangerous half-truths and total nonsense: Profiting from evidence-based management. Cambridge: Harvard Business School Press.

Podolny, J. M., \& Khurana, R., and Hill-Popper, M. 2005. Revisiting the Meaning of Leadership. Research in Organizational Behavior, 26:1-36.

Podsakoff, P. M., MacKenzie, S. B., Lee, J. Y., \& Podsakoff, N. P. 2003. Common method biases in behavioral research: A critical review of the literature and recommended remedies. Journal of Applied Psychology, 88: 879-903.

Rao et al., 2000. Power plays: How social movements and collective action create new organizational forms. In B. M. Staw and R. I. Sutton (eds.), Research in organizational behavior, Vol. 22 (237-282). Greenwich, CT: JAI Press.

Rhodes, R. A. W. 2005. Everyday life in a ministry: Public administration as anthropology. American Review of Public Administration, 35(1): 3-25.

Riccucci, N. M. 1995. Unsung heroes: Federal execucrats making a difference. Wash- 
ington DC: Georgetown University Press.

Selznick, P. 1949. T.V.A. and the grass roots. Berkeley: University of California Press. . 1957. Leadership in administration. New York: Harper and Row.

Terry, L. D. 1995. The leadership-management distinction: The domination and displacement of mechanistic and organismic theories. The Leadership Quarterly, 6(4): 515-527.

Thornton, P. H., \& Ocasio, W. 1999. Institutional Logics and the Historical Contingency of Power in Organizations: Executive Succession in the Higher Education Publishing Industry, 1958-1990. American Journal of Sociology, 105(3): 801-844.

Trottier, T., Van Wart, M., \& Wang, X. H. 2008. Examining the nature and significance of leadership in government organizations. Public Administration Review, 68: 319-333.

Washington, M., Boal, K. B., \& Davis, J. N. 2008. Institutional leadership: Past, present, and future. In R. Greenwood, C. Oliver, R. Suddaby and K. SahlinAnderson (eds.), Handbook of Organizational Institutionalism (721-735). London: Sage.

Wilson, J. Q. 1989. Bureaucracy: What government agencies do and why they do it. New York: Basic Books.

Wofford, J. C., Whittington, J. L., \& Goodwin, V. L. 2001. Follower motive patterns as situational moderators for transformational leadership effectiveness. Journal of Managerial Issues, 13: 196-211. 


\section{APPENDIX}

Appendix Table 1. Descriptive Statistics and Measurement Reliability ( $\mathrm{N}=542)$

\begin{tabular}{|c|c|c|c|c|c|}
\hline Variables & Mean & SD & Minimum & Maximum & Cronbach's alpha \\
\hline Y1 (overall perceived performance) & 5.08 & 1.38 & 1 & 7 & \\
\hline Y2 (perceived policy performance) & 15.16 & 3.85 & 3 & 21 & 0.93 \\
\hline Visionary leadership (factor 1) & 0 & 1 & -4.04 & 2.96 & 0.91 \\
\hline Item 1 & 4.95 & & 1 & 7 & \\
\hline Item 2 & 4.81 & & 1 & 7 & \\
\hline Item 3 & 4.69 & & 1 & 7 & \\
\hline Item 4 & 4.69 & & 1 & 7 & \\
\hline Item 5 & 4.58 & & 1 & 7 & \\
\hline Communicative leadership (factor 2) & 0 & 1 & -3.39 & 3.12 & 0.94 \\
\hline Item 6 & 5.03 & & 1 & 7 & \\
\hline Item 7 & 5.04 & & 1 & 7 & \\
\hline Item 8 & 4.91 & & 1 & 7 & \\
\hline Item 9 & 4.82 & & 1 & 7 & \\
\hline Learning-oriented leadership (factor 3) & 0 & 1 & -4.81 & 2.77 & 0.85 \\
\hline Item 10 & 4.91 & 1.04 & 1 & 7 & \\
\hline Item 11 & 4.81 & 1.29 & 1 & 7 & \\
\hline Item 12 & 4.81 & 1.39 & 1 & 7 & \\
\hline Item 13 & 4.85 & 1.39 & 1 & 7 & \\
\hline Coalition network leadership (factor 4) & 0 & 1 & -3.48 & 3.71 & 0.89 \\
\hline Item 14 & 5.25 & 1.16 & 1 & 7 & \\
\hline Item 15 & 5.21 & 1.16 & 1 & 7 & \\
\hline Item 16 & 5.04 & 1.15 & 1 & 7 & \\
\hline Maintaining leadership (factor 5) & 0 & 1 & -3.28 & 4.12 & 0.51 \\
\hline Item 17 & 3.72 & 1.23 & 1 & 7 & \\
\hline Item 18 & 3.96 & 1.27 & 1 & 7 & \\
\hline Presid (dummy) & 0.45 & 0.50 & 0 & 1 & \\
\hline Threat (dummy) & 0.55 & 0.50 & 0 & 1 & \\
\hline Presid * factor 1 & -0.13 & 0.63 & -3.09 & 2.84 & \\
\hline Presid * factor 2 & -0.09 & 0.71 & -3.39 & 3.08 & \\
\hline Presid * factor 3 & -0.07 & 0.66 & -4.54 & 2.66 & \\
\hline Presid * factor 4 & -0.31 & 0.66 & -3.48 & 1.71 & \\
\hline Presid * factor 5 & 0.01 & 0.52 & -2.55 & 2.23 & \\
\hline Threat * factor 1 & -0.04 & 0.77 & -4.04 & 2.96 & \\
\hline Threat * factor 2 & -0.03 & 0.76 & -3.39 & 3.08 & \\
\hline Threat * factor 3 & -0.04 & 0.77 & -4.81 & 2.77 & \\
\hline Threat * factor 4 & -0.03 & 0.78 & -3.48 & 3.71 & \\
\hline Threat * factor 5 & 0.00 & 0.78 & -3.28 & 4.12 & \\
\hline Bureau (dummy) & 0.52 & 0.50 & 0 & 1 & \\
\hline Age & 58.53 & 4.42 & 48 & 69 & \\
\hline Tenure (days) & 440.9 & 171.9 & 203 & 1,027 & \\
\hline
\end{tabular}

Note: The variable "perceived policy performance" is the sum of three items: policy design, policy implementation, and policy solution. Presid = presidential support; threat = performance crisis. 